\title{
COMUNIDADE E DEMOCRACIA NA SOCIOLOGIA DE T. LYNN SMITH E JOSÉ ARTHUR RIOS*
}

\section{Thiago da Costa Lopes}

Fundação Oswaldo Cruz (Fiocruz), Rio de Janeiro - RJ, Brasil. E-mail: lopes_47@hotmail.com

\section{Marcos Chor Maio}

Fundação Oswaldo Cruz (Fiocruz), Rio de Janeiro - RJ, Brasil. E-mail: maio@fiocruz.br

DOI: $10.17666 / 329516 / 2017$

\section{Introdução}

Neste trabalho investigamos, de um ângulo transnacional, os elementos cognitivos e políticos constitutivos das propostas reformadoras delineadas pelos sociólogos T. Lynn Smith e José Arthur Rios nos anos de 1940 e 1950, tendo em vista a modernização da estrutura social das zonas rurais brasileiras. Transitando por instituiçóes científicas brasileiras e norte-americanas, órgãos governamentais, agências multilaterais e diferentes círculos de cien-

* Uma versão preliminar deste artigo foi apresentada no $10^{\circ}$ Encontro da Associaçáo Brasileira de Ciência Política (ABCP), ocorrido em Belo Horizonte, Minas Gerais, entre 30 de agosto e 2 de setembro de 2016. Gostaríamos de agradecer aos pareceristas anônimos da Revista Brasileira de Ciências Sociais e a Nara Azevedo pelas críticas e sugestóes ao texto.

Artigo recebido em 05/09/2016

Aprovado em 24/05/2017 tistas sociais, técnicos, políticos e reformadores, Smith e Rios desenvolveram programas de engenharia social que resultaram do encontro de distintas correntes intelectuais, vinculadas especialmente à sociologia rural norte-americana, de um lado, e ao pensamento social brasileiro, de outro. Enfocamos aqui o impacto de matrizes locais de pensamento sobre esses dois autores. Argumentamos, mais precisamente, que as teses de Oliveira Vianna em Populaçóes meridionais do Brasil (1920), mormente suas proposiçóes relativas ao insolidarismo e ao papel simplificador do latifúndio sobre a estrutura social brasileira, forneceram coordenadas intelectuais fundamentais a partir das quais Smith e Rios operaram a leitura da realidade social do país.

A exploração dos liames entre as ideias de $\mathrm{T}$. Lynn Smith, José Arthur Rios e Oliveira Vianna nos permite aquilatar mais bem a dimensão transnacional da produção do conhecimento sociológico ocorrida no passado. A abordagem transnacional, 
enfocando as conexóes e a circulação de atores e ideias entre diferentes regióes do globo (Saunier, 2004; Secord, 2004), justifica-se quando se considera a importância que tem assumido, para a história das ciências contemporâneas, a revisão das leituras difusionistas, segundo as quais a ciência moderna teria sido um produto exclusivamente europeu e norte-americano, propagando-se posteriormente para o restante do mundo. ${ }^{1}$ No âmbito da história das ciências sociais, em que pesem as assimetrias que marcaram a produção e a circulação das ideias sociológicas, expressas, desde o fim da Segunda Guerra Mundial, pela crescente hegemonia dos padróes organizacionais e cognitivos das ciências sociais norte-americanas, estudos transnacionais têm chamado a atenção para as fontes heterogêneas que constituíram diferentes tradições de conhecimento, não mais concebendo-as apenas a partir de enquadramentos nacionais estanques e autorreferidos (Heilbron et al., 2008), e para as ideias e os espaços de circulação compartilhados entre cientistas sociais de diversos países, tanto ao Norte como ao Sul do globo (Rosemblatt, 2014). No Brasil, não só o papel de agências multilaterais e de tradiçóes disciplinares estrangeiras tem sido examinado no tocante ao desenvolvimento das ciências sociais (Maio, 1997; Villas Bôas, 2006a), mas também a produção sociológica local tem sido estudada com base em molduras históricas mais amplas, que indicam as trocas ou as similitudes com ideias gestadas em cenários igualmente periféricos (Brasil Jr., 2011; Maia, 2011). Ao analisar o papel das teses de Oliveira Vianna na produção sociológica de T. Lynn Smith sobre o Brasil, assim como sua repercussão posterior nos trabalhos de José Arthur Rios, um dos continuadores da sociologia rural de matriz norte-americana representada por Smith, buscamos conferir maior complexidade ao estudo dos fluxos de ideias entre centro e periferia, contribuindo, desse modo, para a desprovincialização da história do pensamento social no Brasil. ${ }^{2}$

As propostas de intervenção social de T. Lynn Smith e José Arthur Rios inserem-se no contexto das políticas de assistência técnica e desenvolvimento regional capitaneadas pelo Estados Unidos no pós-Segunda Guerra e nos anos da Guerra Fria, quando a ideia de desenvolvimento ganha força no imaginário social e político global. Partindo-se da noção de destino histórico comum entre as diferentes regióes do mundo, a situação socioeconômica dos países periféricos passou a ser enxergada como sintoma do atraso a ser vencido mediante a cooperação internacional (Escobar, 1996). No Brasil, a questão do desenvolvimento esteve associada à perspectiva de indução do crescimento econômico por meio de ações planejadas visando à construção de uma sociedade capitalista de tipo industrial (Bielschowsky, 1995). Em um processo de expansão da presença do poder público pelo território nacional, o Estado implementou políticas de desenvolvimento regional com investimentos em infraestrutura básica e exploração dos recursos naturais (Costa Lima, 2011). Nesse período, as expressões "mudança social” e "resistências à mudança” tornaram-se recorrentes nos debates travados em torno do papel a ser desempenhado pelos cientistas sociais nas atividades de planejamento e intervenção social (Villas Bôas, 2006b; Maio e Lima, 2009).

Inicialmente, analisamos a produção intelectual de Smith e Rios, marcada pela reivindicação da aplicabilidade do conhecimento sociológico, atentando para suas respectivas trajetórias. Em segui$\mathrm{da}$, no intuito de explorar os valores políticos e os ideais de sociedade implícitos nas concepçóes que desenvolveram acerca das comunidades rurais brasileiras, cotejamos as perspectivas sociológicas de ambos com aquela adotada por Oliveira Vianna em Populaçóes meridionais do Brasil. Ao mesmo tempo que foi decisiva para a decodificação dos princípios estruturantes da sociedade brasileira por parte de Smith e Rios, a matriz autoritária de pensamento que se manifesta na obra de Vianna colocou em tensão as propostas de intervenção social desses dois sociólogos, que tinham em mira a efetivação da democracia política mediante a construção de uma cultura cívica no país.

\section{Transformando o caboclo em farmer}

Thomas Lynn Smith (1903-1976) se encontra entre os sociólogos que, no contexto de expansão global das ciências sociais norte-americanas que teve início durante a Segunda Guerra Mundial 
(Heilbron et al., 2008), visitaram diversas vezes o Brasil, desenvolvendo atividades de ensino e pesquisa. Embora constitua um capítulo da presença de cientistas sociais estrangeiros no país, ${ }^{3}$ assim como elemento importante para a compreensão do desenvolvimento das ideias sociológicas sobre o mundo rural brasileiro, ${ }^{4}$ a obra de Smith sobre o Brasil ainda não foi objeto de estudo sistemático.

Oriundo de uma família de pequenos fazendeiros mórmons de Sanford, Colorado, Smith ingressou no curso de sociologia rural da Universidade de Brigham Young por sugestão de Lowry Nelson, que conhecera durante o trabalho de jovem missionário. ${ }^{5}$ Em 1928, ele iniciou a pós-graduação na Universidade de Minnesota, onde foi aluno de Pitrim Sorokin e Carle Zimmerman, realizando ainda um ano de estudos na Universidade de Harvard. Em 1931, o sociólogo foi indicado para o cargo de professor assistente na Universidade Estadual de Louisiana, onde iniciou sua carreira acadêmica. ${ }^{6}$ Smith integrou uma geração de sociólogos rurais posta a serviço das políticas do New Deal, de recuperação econômica e assistência social às populaçóes rurais, cujos trabalhos se desenvolveram em estreita associação com as Estaçóes Experimentais Agrícolas dos Estados Unidos. Sua bolsa de pós-graduação foi obtida graças à política lançada em 1927 pelo Social Science Research Council (SSRC) visando à formação acadêmica daqueles que, na qualidade de sociólogos rurais, vinham assumindo postos de trabalho subsidiados pelo governo federal nas estações experimentais (Smith e Montiel, 1958). Smith foi, ademais, um dos atores envolvidos na construção do campo da Sociologia Rural naquele país, tendo sido o fundador da revista Rural Sociology, que dirigiu de 1936 a 1941, e o primeiro secretário da Rural Sociological Society, criada em 1937.

T. Lynn Smith voltou seus interesses para a América Latina em meados dos anos de 1930, em um momento em que o trabalho de campo no exterior se tornava cada vez mais comum entre os sociólogos norte-americanos. Em 1935, ele havia acompanhado seu antigo professor Carle Zimmerman a uma viagem de estudos ao México, retornando a este país em 1938 (Smith e Montiel, 1958). Particularmente importante para a aproximação de Smith com o Brasil foi o contato com Robert Park, que, no início dos anos de 1930, costumava discorrer sobre seus interesses acadêmicos envolvendo o país em visitas ao professor da Universidade Estadual de Louisiana (Smith, 1974, p. 250). ${ }^{7}$ Em 1939, durante uma viagem pela América Latina financiada pela Fundação Julius Rosenwald, Smith visitou pela primeira vez o Brasil, permanecendo no país por algumas semanas. $\mathrm{Na}$ ocasião, travou contato, entre outros, com Donald Pierson, ex-aluno de Park e professor da Escola de Sociologia e Política de São Paulo, e Arthur Ramos, catedrático de antropologia da Universidade do Brasil. ${ }^{8}$

Ao longo dos anos de 1940 e 1950, valendo-se da Política de Boa Vizinhança e, posteriormente, do Ponto IV - programa de assistência técnica ao denominado terceiro mundo lançado pelo Governo Truman -, Smith tornou a empreender viagens ao Brasil, ora em missóes oficiais do Estado norte-americano ora como professor visitante, conferencista e representante de agências internacionais, buscando tecer uma rede de trocas acadêmicas com cientistas sociais em atuação no país. Em fevereiro de 1942, em meio aos esforços de guerra que levaram o governo norte-americano a convocar sociólogos rurais para missóes de estudo em países da América Latina, ${ }^{9}$ Smith foi designado pelo Auxiliary Foreign Service do Departamento de Estado, em uma iniciativa conjunta com o Office of Foreign Agricultural Relation do Departamento de Agricultura, para assumir a função de analista agrícola na Embaixada Americana do Rio de Janeiro, trabalhando durante um ano com o adido agrícola Erwin P. Keeler. ${ }^{10}$ Segundo Smith, M. L. Wilson, diretor dos Serviços de Extensão Agrícola dos Estados Unidos, desempenhou papel-chave no desenvolvimento dessas missóes, ao propor que os sociólogos rurais de seu país contribuíssem para o processo de racionalização da agricultura entre as populações rurais latino-americanas (Smith e Montiel, 1958). A iniciativa, que se somava aos programas destinados ao aumento da produtividade do trabalhador rural, foi uma das respostas do governo norte-americano, no plano da assistência técnica internacional, ao crescimento da demanda por matérias-primas provenientes da região que se seguiu ao início da Segunda Guerra Mundial (Loomis, 1942). 
Em 1946, Smith publicou Sociologia da vida rural, edição brasileira do livro lançado em 1940 nos Estados Unidos, que se propunha a realizar uma síntese dos estudos em sociologia rural em curso naquele país, sistematizando os fundamentos, o objeto e os principais problemas de pesquisa da disciplina. O processo de publicaçáo foi intermediado por Arthur Ramos e ficou a cargo da Editora da Casa do Estudante do Brasil, entidade de assistência estudantil que desenvolvia atividades de intercâmbio cultural e que foi o berço da Uniáo Nacional dos Estudantes (Poerner, 2004). Ainda em 1946, com base em suas incursóes pelo Brasil, Smith lançou, pela Universidade Estadual de Louisiana, a obra monumental Brazil: people and institutions, que reuniu o resultado de suas investigaçóes sociológicas sobre o país. No ano seguinte, após ingressar no corpo docente da Universidade de Vanderbilt, no Tennessee, o sociólogo fundou o primeiro centro norte-americano de estudos interdisciplinares destinado ao gigante da América do Sul, o Institute for Brazilian Studies, conseguindo atrair estudiosos do Brasil para ministrar cursos de verão na instituição, a exemplo de Antônio Carneiro Leão, Emílio Willems e José Arthur Rios. Ao lado do historiador Alexander Marchant, Smith organizou Brazil, portrait of half a continent (1951), denso volume que contou com a contribuição de cientistas sociais como Arthur Ramos, Roger Bastide, Antonio Candido e José Arthur Rios. Em 1949, Smith se tornou professor de Sociologia da Universidade da Flórida.

Nos anos de 1950, a atuação de Smith no Brasil esteve ligada a atividades de aconselhamento técnico e à participação em diversas conferências, especialmente em torno do tema da reforma agrária. Em 1952, após avaliar os trabalhos da Comissáo Nacional de Política Agrária, instalada pelo Segundo Governo Vargas, o sociólogo esboçou, por meio de memorando, um programa de redistribuição de terras para o país a pedido do ministro da Agricultura João Cleofas. No ano seguinte, ele participou, como observador da Organizaçáo Internacional do Trabalho, do Seminário de Bem-Estar Social Rural da América Latina, realizado no Rio de Janeiro sob os auspícios do governo brasileiro. Em 1956, em missão do Departamento de Estado norte-ameri- cano, Smith tornou a tratar da questáo fundiária ao realizar uma série de conferências em diversas capitais do país. ${ }^{11}$ Em 1959, atendendo à solicitação do Seminário Internacional sobre Resistências à Mudança, promovido pelo Centro Latino-Americano de Pesquisas em Ciências Sociais, o sociólogo enfocou o problema da mudança social nas denominadas áreas subdesenvolvidas, apontando o latifúndio como um dos maiores obstáculos ao desenvolvimento (Smith, 1959).

T. Lynn Smith era especialmente crítico em relaçấo às grandes monoculturas de algodáo e cana-de-açúcar características do Deep South, formado pelas zonas rurais de Estados sulistas como Geórgia, Alabama, Mississipi e Louisiana, que compartilhavam um passado fortemente escravocrata. A plantation constituía um "complexo cultural" fundado em "relaçôes paternalísticas" entre lavradores e proprietários que estava na raiz do quadro de pobreza, ignorância e apatia de regióes como o Delta do Mississipi (Smith, 1937, p. 146). Privilegiando a análise das relações entre formas de povoamento, divisão da terra e os tipos de organização social daí decorrentes, a sociologia de Smith apresenta como horizonte normativo um mundo rural formado por comunidades de fazendas familiares, visão que remonta ao imaginário social em torno do Midwest norte-americano e aos ideais jeffersonianos de uma democracia fundada na ação política virtuosa de pequenos fazendeiros independentes (Cronshaw, 1982). Essa perspectiva sociológica se evidencia nos estudos realizados por Smith na Universidade Estadual de Louisiana nos anos de 1930, especialmente quando trata das políticas de colonização que seriam mais favoráveis a uma vida comunitária de ajuda mútua, de envolvimento cívico com as associaçóes e instituiçóes locais, e integrada ao mercado e aberta aos padróes de consumo dos centros urbanos industriais (Smith, 1934, 1935).

É patente nesses trabalhos que, com frequência, se debruçam sobre os efeitos sociais dos programas de assistência às populações rurais lançados pelo governo norte-americano durante a Grande Depressão, o desejo de Smith de ver suas ponderaçóes incorporadas às atividades de planejamento governamental. Embora sua concepção de sociologia esteja alicerçada em uma visáo da ciência como 
empreendimento intelectual empiricamente orientado e voltado prioritariamente para o acúmulo de conhecimento teórico (Smith, 1946, pp. 21-30), e suponha a divisão entre pesquisas pura e aplicada, na prática, Smith não observa tais fronteiras de maneira rigorosa, sendo frequente, mesmo em seus textos de natureza acadêmica, a passagem automática de esforços descritivos e analíticos para recomendações de caráter prático visando à promoção do bem-estar social rural (Idem, p. 555). Esse fato se torna inteligível quando se considera que os sociólogos norte-americanos, sob o influxo de novas possibilidades de atuação profissional suscitadas pelo New Deal, que beneficiaram especialmente economistas e cientistas políticos, passaram a explorar sistematicamente a relevância da sociologia para o enfrentamento das questóes da agenda pública, acomodando tais aspiraçóes utilitárias no interior das antigas posiçôes cientificistas que vinham se cristalizando no interior do campo acadêmico desde o início do século XX (Camic, 2007). O recrutamento de sociólogos por parte de agências do Estado que se seguiu à irrupção da Segunda Guerra Mundial reforçou a aproximação entre o mundo acadêmico e a esfera da ação prático-política, suscitando debates em torno da legitimidade de um domínio que passou a ser comumente referido como sociologia aplicada (Lazarsfeld e Reitz, 1989).

A inspiração de Smith para políticas de colonização que estimulassem o fortalecimento das comunidades locais foi buscada no padrão de ocupação territorial de famílias de ascendência francesa que trabalhavam como lavradores no sul do Estado de Louisiana. $\mathrm{Na}$ visão do sociólogo, tratava-se de uma alternativa tanto à forma de colonização predominante na história norte-americana, baseada na fixação de fazendas dispersas (isolated farmsteads) que resultava em isolamento social, quanto à comunidade de aldeia (village community) europeia, tipo de povoaçấo nucleada que, embora fosse propícia à cooperação social, representava elevados custos para o agricultor, dada a distância entre sua residência e as terras destinadas ao cultivo (Smith, 1934, p. 681). ${ }^{12}$

Smith acreditava que as comunidades rurais viriam a desempenhar um papel destacado na vida social norte-americana. A seu ver, a tendência era que a comunidade suplantasse o grupo de vizi- nhança (famílias vivendo em proximidade) como a menor unidade social constitutiva da sociedade nacional. Graças à expansão dos modernos meios de comunicação e transporte, estava em curso um processo de diferenciação socioeconômica que implicava maior interdependência entre os núcleos rurais e urbanos dos Estados Unidos. Estabelecendo contato frequente com centros comerciais regionais, para além dos pequenos armazéns locais, as famílias rurais alargavam seus horizontes sociais e criavam vínculos para além dos círculos de parentesco e dos grupos circunvizinhos. A comunidade rural norte-americana formava-se gradativamente a partir de uma teia de relaçóes que se estendia por toda a área de fazendas sob a influência de um pequeno centro comercial, sendo o resultado da fusão de grupos de vizinhança até então isolados e autossuficientes (Smith, 1940).

As reflexôes de Smith sobre a comunidade rural serão estendidas ao Brasil a partir de suas primeiras viagens ao país no início dos anos de 1940. Em dezembro de 1943, após regressar de sua primeira missão oficial, Smith apresentou uma análise da "estrutura dos grupos de localidade" do Brasil na reunião anual da American Sociological Society. À semelhança do que ocorria nos Estados Unidos, as comunidades brasileiras não constituíam núcleos de habitação densamente povoados e, por esta razão, dificilmente eram discerníveis na paisagem rural. Seus agrupamentos sociais fundamentais, as famílias e as vizinhanças, encontravam-se dispersos por vastas extensóes de terra enquanto uma vila, sede de distrito ou sede municipal, desempenhava timidamente as funções comerciais, educacionais e administrativas da localidade. Smith remete esse padrão comunitário ao processo de colonização, responsável por um tipo de ocupação do território baseado em fazendas isoladas, em sua maior parte latifúndios que por muito tempo haviam concentrado as atividades socioeconômicas fundamentais (Smith, 1944).

$\mathrm{Na}$ visão de Smith, as relações entre o centro urbano representado pela sede municipal e a população dispersa dos arredores tendiam a se estreitar, havendo elementos característicos da sociedade brasileira favoráveis a esta integração. Enquanto nos Estados Unidos a lei permitia que as cidades 
do interior adquirissem autonomia político-administrativa, desvinculando-se das áreas rurais circunvizinhas, os municípios brasileiros abrangiam tanto as vilas que lhes serviam de sede como os distritos e zonas rurais sob sua influência direta (Idem). Ademais, a relativa homogeneidade religiosa, com o predomínio da Igreja Católica no país, somada à ausência de clivagens segundo linhas de cor entre os grupos de vizinhança contribuíam para tornar menos intrincada a estrutura das comunidades brasileiras, reforçando sua coesão interna, à diferença do que se observava nos Estados Unidos (Idem, p. 44).

As comunidades rurais do país, contudo, permaneciam, em sua maioria, em um "estado amorfo" (Idem, p. 47). O isolamento geográfico do campo, os fortes vínculos entre as famílias, o predomínio da agricultura de subsistência entre as camadas pobres, a autossuficiência econômica do latifúndio e a rígida estrutura de classes eram os fatores que dificultavam, ao lado da baixa escolaridade da população, o desenvolvimento de uma vida comunitária mais ampla, para além das relaçóes de parentesco.

$\mathrm{Na}$ leitura que realiza da realidade brasileira, Smith se apoia na conhecida tese do insolidarismo, expressa classicamente em Populaçóes meridionais do Brasil, de Oliveira Vianna, segundo a qual haveria uma "carência de instituiçóes de solidariedade social em nosso povo" (Oliveira Vianna, [1920] 1938 , p. 205), isto é, de formas de associação ou "ação em conjunto" visando a interesses ou utilidades comuns, como as tradiçôes de cooperação vicinal ou os conselhos comunais europeus (Idem). ${ }^{13}$ A amorfia da sociedade resultava do predomínio do grande domínio rural, com sua independência socioeconômica, no processo de ocupação do território brasileiro, que ensejara círculos de solidariedade restritos aos clâs patriarcais e às famílias, constituindo a "única forma de solidariedade social que realmente sentimos, [...] única que realmente praticamos" (Idem, p. 219, grifo do autor).

Afinado com as observações de Oliveira Vianna acerca do peso da solidariedade clânica e parental na história social do Brasil, Smith afirma que os vínculos entre famílias vizinhas absorviam quase que por inteiro as preocupaçóes dos indivíduos, restando muito pouco para o desenvolvimento de atividades em "áreas maiores e mais completas de interação social, tal como a comunidade" (Smith, 1944 , p. 46). Smith também retoma a tese do autor de Populaçôes meridionais do Brasil concernente ao papel simplificador do latifúndio ao notar que o sistema de produção agrícola brasileiro, baseado em grande medida na prática das queimadas, havia representado uma regressão em relação às formas de cultivo praticadas em Portugal à época da colonização. Para o sociólogo norte-americano, o caboclo e o sertanejo, destituídos de propriedade, habituavam-se à miséria e às primitivas técnicas agrícolas herdadas da cultura indígena, mantendo-se em um horizonte estreito de aspiraçóes. Apoiando-se em estudos sobre renda e alimentação de famílias operárias de Recife desenvolvidos nos anos de 1930 pelo médico e geógrafo Josué de Castro, que haviam assinalado as relaçóes entre consumo interno deficiente, monocultura e concentração fundiária (Bizzu, 2009), Smith constata que o grosso da população brasileira era marcado por baixos níveis de vida (Smith, 1946, p. 349).

Smith não hesita em apontar medidas capazes de acelerar o ritmo do processo de integração das comunidades rurais e incrementar suas condiçóes de vida. Era preciso investir na infraestrutura de transportes e comunicação, bem como introduzir técnicas agrícolas modernas, capazes de aumentar a produtividade do trabalho e alterar os padróes de vida das massas rurais, criando-lhes novas necessidades que as vinculassem mais estreitamente aos centros urbanos. A modernização das técnicas produtivas exigia, por sua vez, transformaçóes culturais visando à remodelação das atitudes e dos valores do homem do campo, o que só poderia ser alcançado mediante o fortalecimento de políticas sociais de âmbito local. Smith aposta, sobretudo, no papel da escola pública municipal no desenvolvimento de comunidades "altamente integradas em grupos sociais operantes" (Smith, 1944, p. 49).

No livro Brazil, people and institutions, cuja primeira edição foi publicada ao tempo em que, com o fim do Estado Novo, instalava-se a nova Assembleia Constituinte, Smith discute com mais vagar a necessidade de aumento das atribuiçóes dos governos locais, enfraquecidos pelo caráter centralizador da Constituição de 1937, e adverte que "os líderes brasileiros não [deviam] tentar fazer tudo do 
Rio de Janeiro" (Smith, 1946, p. 793). O município, a unidade político-administrativa elementar da nação, cujos limites tendiam a coincidir, a seu ver, com os da comunidade em formação, devia dispor de formas de arrecadação ligadas à taxação progressiva das propriedades rurais sob sua jurisdição a fim de poder custear, por conta própria, os serviços essenciais de "proteção à vida e à propriedade, saúde, bem-estar, educaçáo e estradas" (Idem, p. 793). Cada município devia reservar um percentual de seus recursos para a manutençáo de ao menos uma escola secundária (Idem).

A aposta de Smith na capacidade de o município levar a cabo parte substantiva do programa de reformas fundava-se na crença de que as instituiçóes políticas locais representavam o canal preferencial para a expressão das demandas da população e o centro aglutinador dos esforços coletivos em prol da comunidade. Trata-se de um ideal político de ordenamento da sociedade, cujo sentido é evidenciado por uma declaração do sociólogo reproduzida pela imprensa brasileira durante sua visita ao país em 1952, quando, por solicitação de Joáo Cleofas, ministro da Agricultura de Vargas, Smith redigiu um memorando contendo as diretrizes para a implementaçáo de reformas estruturais no campo:

A experiência mundial [...] é que quaisquer deficiências que possa apresentar o autogoverno num humilde município rural - deficiências culturais ou técnicas - são amplamente compensadas pela honestidade, pela virtude de cidadãos que se conhecem e que executam, com suas próprias mãos e seus próprios recursos, obras que estáo diante da vista de todos (Correio da Manhä, 1952).

Mesmo admitindo que inspeçôes federais ou estaduais fossem eventualmente necessárias para o controle dos fundos, Smith afirmava, em seu memorando, que a aplicaçáo local de recursos arrecadados pelo próprio município representava a melhor garantia possível contra o uso indevido ou o desvio de verbas (Smith, 1963, p. 130).

A taxaçáo progressiva da propriedade rural pelo município, além de assegurar os recursos necessários à prestação de serviços, viria a desestimular a reten- çáo da terra para fins especulativos, abrindo o caminho para programas governamentais de aquisição e parcelamento do latifúndio em pequenas e médias propriedades familiares, pedra angular da reforma agrária proposta pelo sociólogo norte-americano. Era preciso assegurar a propriedade da terra, em extensão limitada às necessidades de uma família, àqueles que provassem sua disposição e capacidade para cultivá-la. Smith estava convencido da urgência de o Estado brasileiro adotar uma política nesses moldes. Tratava-se de momento propício: por força do crescimento vegetativo da populaçáo, principalmente entre as elites rurais, que tinham prole numerosa, os antigos latifúndios estavam se fragmentando no processo de partilha das heranças (Smith, 1946, p. 511). No caso das zonas de fronteira agrícola, o Estado devia se pautar por programas de colonizaçáo que priorizassem o assentamento de famílias de lavradores, preferencialmente de colonos da regiấo Sul do país e, eventualmente, de imigrantes europeus que, a par das técnicas agrícolas modernas, eram, por excelência, os agentes de difusão de padróes culturais mais avançados (Smith, 1947b).

Conjugando autonomização dos governos locais, municipalizaçáo dos serviços de educação e saúde, taxação da propriedade fundiária e políticas nacionais de fixação de fazendas familiares, o modelo de intervenção proposto por Smith visava à consolidação de uma classe média de agricultores no Brasil em substituição à rígida e pouco diferenciada estrutura de classes gestada por séculos de latifúndio e escravidão. Em 1946, em conferência no Conselho Nacional de Geografia, o sociólogo afirmou que era preciso transformar sertanejos e caboclos, assim como os segmentos decadentes das famílias senhoriais, em farmers e lavradores ativos, membros de uma classe média de fazendeiros aptos a exercer simultaneamente as funçóes de capitalista-empreendedor, administrador-gestor e trabalhador (Smith, 1947b, p. 171).

O déficit social identificado por Oliveira Vianna na formação histórica do Brasil - a ausência das classes médias rurais - devia, e podia, ser superado, combinando-se reformas legislativas que permitissem maior participação dos municípios na promoção do bem-estar geral e políticas de Estado sociologicamente fundamentadas visando à re- 
distribuição da propriedade fundiária. A reforma agrária, garantindo ao lavrador a posse da terra, era o melhor caminho para se formar personalidades com iniciativa, ciosas de seus bens e níveis de vida, e aptas a exercer a cidadania política (Smith, 1946 , p. 483). Nos primórdios da Guerra Fria, a complexificação da estrutura social brasileira, com a ascensão e a integração dos contingentes rurais ao mercado e ao mundo dos direitos, foi a resposta de Smith em face da ameaça representada pelo comunismo, que tinha, a seu ver, todas as condiçóes para se disseminar entre as massas empobrecidas e despossuídas (Smith, 1952). Não à toa, o sociólogo recomendou estratégias de modernização social em linhas semelhantes em suas atividades posteriores de aconselhamento técnico na América Latina, a exemplo do auxílio que prestou ao governo colombiano na elaboração de programas de reforma agrária e colonização (Lorek, 2013).

\section{Educação e saúde para a cidadania}

As formas de intervenção social que José Arthur Rios associou à sua análise sociológica da realidade social brasileira estiveram informadas por debates transnacionais sobre as relaçóes entre planejamento, desenvolvimento e organização de comunidades. Há forte convergência entre a sociologia de Rios, cujo enfoque incide sobre a comunidade e a relação entre estrutura fundiária e organização social, e a visão dos problemas sociais do campo de T. Lynn Smith, com quem manteve vínculos intelectuais desde sua passagem pela Universidade Estadual de Louisiana no imediato pós-guerra.

Formado em Direito no início dos anos de 1940 pela Universidade do Brasil, onde também frequentou os cursos de ciências sociais da então recém-criada Faculdade Nacional de Filosofia, Rios se manteve próximo aos círculos de reformadores e militantes católicos da capital federal que se reuniam no Centro Dom Vital. ${ }^{14}$ Nos estertores do Estado Novo, ele integrou a denominada "Resistência Democrática", movimento heterogêneo do ponto de vista político-ideológico que reuniu considerável número de intelectuais, entre advogados, médicos e professores, avessos ao regime de Vargas. ${ }^{15}$ Contan- do com participantes como José Fernando Carneiro, Adauto Lucio Cardoso, Gustavo Corção, Carlos Lacerda, Sobral Pinto e Mário Pedrosa, o grupo, que atuou contra o queremismo nos jornais, ${ }^{16}$ é considerado por Rios uma escola de formação política. Posteriormente, Rios viria a militar nas fileiras do Partido Libertador, liderado por Raul Pilla, que se caracterizou pela defesa do regime parlamentarista, tendo sido, ao lado da Uniāo Democrática Nacional, um dos principais partidos de oposição aos governos de Vargas, Kubitscheck e Goulart (Leal e Flaksman, 1984).

Em 1945, Rios travou contato com Smith por meio de Hilgard Sternberg, colega do curso de geografia, ${ }^{17}$ conseguindo uma bolsa para realizar o mestrado em sociologia rural sob a orientação de Smith na Universidade Estadual de Louisiana. A convite de Smith, Rios retornou aos Estados Unidos em 1948 como professor visitante da Universidade de Vanderbilt e, em 1952, a fim de ministrar cursos de verão na Universidade da Flórida. As conexões de Rios se estenderam à França, em 1950, quando se aproximou do movimento Économie et Humanisme, tomando conhecimento do modelo de intervenção social desenvolvido pelo frei dominicano Louis-Joseph Lebret.

No Brasil, na primeira metade dos anos de 1950, Rios se envolveu em importantes iniciativas governamentais nas áreas de educação e saúde. Entre 1951 e 1952, o sociólogo coordenou a Campanha Nacional de Educação Rural (CNER), lançada pelo Ministério da Educação sob forte inspiração das missóes rurais mexicanas e das técnicas de educação de adultos veiculadas pela Unesco, ${ }^{18}$ tendo participado igualmente da Comissão Nacional de Política Agrária, que se debruçou sobre o problema da reforma agrária. A partir de 1953, Rios dirigiu a Seção de Pesquisas Sociais da Divisão de Educação Sanitária do Serviço Especial de Saúde Pública (Sesp), órgão nascido de acordo bilateral entre Brasil e Estados Unidos e que, desde sua criação, valeu-se do trabalho de cientistas sociais na implementação de programas de saúde. ${ }^{19}$ Em fins da década de 1950, Rios assumiu a direção do Escritório da Sociedade de Análises Gráficas e Mecanográficas Aplicadas aos Complexos Sociais (Sagmacs) do Rio de Janeiro, agência particular de pesquisa e pla- 
nejamento social criada nos moldes de instituição congênere fundada por Lebret na França. À frente da Sagmacs, o sociólogo conduziu estudos sobre as condiçôes de vida das populaçóes rurais de diversos municípios brasileiros, além de ter coordenado ampla pesquisa em favelas na cidade do Rio de Janeiro (Valladares, 2012).

A viagem de Rios aos Estados Unidos foi fator decisivo em sua trajetória intelectual. Em crônicas redigidas para $O$ Globo durante o mestrado na Universidade de Louisiana, ele registrou suas impressóes da sociedade norte-americana, que enxerga sob o prisma tocquevilliano das liberdades e da igualdade, contrapondo-a à cultura política dos países latino-americanos, de caráter autoritário e hierarquizante. As ponderaçóes de Rios sobre os Estados Unidos inserem-se no contexto da redemocratização brasileira, da nova Assembleia Constituinte, e póem-se em sintonia com as tentativas de balanço crítico do regime ditatorial:

Sempre que problema novo surge a desafiar a nação [norte-americana], os líderes que o percebem não vão clamar ao Congresso que conceda poderes extraordinários ao Executivo para que o resolva, mas descem à rua, dirigem-se ao homem comum, avisam-no e instruem-no, para que ele soberanamente decida (Rios, 1946b).

A forte tradição de participação política dos Estados Unidos deveria ser buscada na forma de organização de sua sociedade e nos valores que desposava, inexistindo preconceitos em relação ao trabalho ou barreiras intransponíveis à ascensão social. ${ }^{20}$ Uma cultura igualitária e democrática era instilada, desde cedo, nos futuros cidadãos por meio de suas principais instituições. Das diversas observações de Rios a esse respeito, dignas de nota são aquelas relativas aos refeitórios das universidades:

[A] civilização americana acostuma [o homem] a comer em perfeita igualdade de classes. $\mathrm{Na}$ cafeteria, não há barreiras sociais, todos são iguais perante o prato, o que prenuncia que serão iguais diante da lei. Ali não se encontra esse monumento de servilismo e degradação humana que a civilização plutocrática criou: o gar- çom. Cada um serve a si mesmo. Empunha-se uma bandeja e, em fila, professores, reitores e alunos (não há precedência), vão empilhando sobre a mesma os pratos que mais lhes falam à gula igualitária (Rios, 1946a).

Os anos de estudo nos Estados Unidos também alimentaram as expectativas de Rios quanto ao potencial prático das ciências sociais. ${ }^{21}$ Desde fins dos anos de 1940, quando de seu retorno ao Brasil, ele buscou ressaltar o papel a ser desempenhado por cientistas sociais na área de políticas públicas tendo em vista a remodelação do mundo rural do país. Fazia-se necessário um programa experimental de pesquisas aplicadas à semelhança do que fizera o Governo Franklin Roosevelt anos antes nos Estados Unidos:

Planejar é experimentar. Dessa experimentação, nos Estados Unidos, surgiram a TVA [Tennessee Valley Authority, programa federal de desenvolvimento regional do Vale do Tennessee], as comissóes de planejamento regional e as comunidades rurais planificadas que constituem verdadeira revolução em sociologia aplicada (Rios, 1948c).

Ao argumentar que a pesquisa em ciências sociais era instrumental para que os governos avaliassem as dificuldades e antecipassem os efeitos de uma intervenção organizada no meio rural (Rios, 1948a), Rios se apoia, ainda, em trabalhos de cientistas sociais que vinham conduzindo estudos de comunidade no Brasil, ${ }^{22}$ como o antropólogo Emílio Willems, que conhecera na Universidade de Vanderbilt durante os cursos de verão de 1948. À semelhança de Willems, o sociólogo afirma que a solução dos problemas sociais rurais implicava a indução de processos de mudança social e cultural. Rios tinha em mente, em particular, o texto $O$ problema rural brasileiro do ponto de vista antropológico, publicado por Willems em 1944 . Nele, o antropólogo considera a experiência norte-americana de colaboração entre sociólogos rurais e agências do Estado como ilustrativa da possibilidade de aplicação das ciências sociais (Willems, 1944, p. 29). Esta postura era condizente com a defesa que vinha fazen- 
do da necessidade de ampliação das frentes de atuação profissional dos cientistas sociais para além das universidades, questão que foi igualmente ventilada, na década de 1940, por Arthur Ramos, catedrático de antropologia da Faculdade Nacional de Filosofia, e por Alberto Guerreiro Ramos, então às voltas com cursos de sociologia em órgãos públicos. ${ }^{23}$

Ao mesmo tempo que condena a pesquisa como um fim em si mesmo, Rios se preocupa em reafirmar a importância do distanciamento do cientista em relação à intervenção propriamente dita. A forma como Rios enxergou o significado e os limites do trabalho dos cientistas sociais em contextos não acadêmicos guarda afinidades com os debates acerca dos usos sociais da sociologia e da antropologia nos Estados Unidos, marcados por tensas relaçóes entre a postura cientificista, e sua conhecida defesa da neutralidade axiológica, de um lado, e o crescente envolvimento de sociólogos e antropólogos, especialmente após a Segunda Guerra Mundial, com a esfera da ação prático-política. Nas palavras de Rios:

[Quando] se assanha no sociólogo [a] vontade de execução, quando ele exorbita de suas funçóes de consultor para provar a mão em tarefas de planejamento e controle, podemos afirmar que está pondo em perigo sua vocação própria, que é o estudo despreconcebido [sic] dos fatos sociais (Rios, 1953 c, p. 2). ${ }^{24}$

No tocante às formas de intervenção, Rios avalia que as técnicas norte-americanas de organização rural podiam ser aplicadas ao Brasil, que vinha sofrendo problemas semelhantes àqueles enfrentados décadas atrás pelos Estados Unidos, como o êxodo rural, o isolamento social e geográfico do homem do campo e o latifúndio improdutivo (Rios, 1947, p. 8). O que estava em jogo era a extensão dos serviços de educação, saúde e assistência ao campo, a integração de suas populações à nação e a reforma agrária fundada no sistema de pequenas fazendas familiares. Era preciso evitar que o "nosso matuto se tornasse presa das doutrinas que lhe acenam com o rádio, o automóvel e a geladeira em troca da liberdade" (Idem, ibidem). Estando na raiz das desigualdades sociais, o latifúndio fora uma das causas desencadea- doras da crise política que redundara no regime de 1937, preparando "o caminho para as forças antidemocráticas, para a sublevação social e a anarquia que viriam colocar o país no dilema - comunismo ou ditadura” (Rios, 1948b). Rios argumenta que o destino da democracia brasileira dependia de profundas reformas na estrutura social do campo.

Além de estar em sintonia com a sociologia de Smith, a visão de Rios sobre o mundo rural é em grande medida informada pelo diagnóstico de Oliveira Vianna acerca do insolidarismo. Em sua leitura de Populaçóes meridionais no Brasil, Rios enfatiza as profundas desigualdades produzidas pela estrutura fundiária, identificando-as como o principal fator inibidor de formas de solidariedade para além dos círculos parentais. Na perspectiva do sociólogo, a "extensão desusada do grupo familiar" entre as elites latifundiárias e escravagistas, ocasionada por sua "riqueza e poder", havia historicamente inviabilizado a organização de grupos sociais diversificados (Rios, 1950a, p. 130). Exercendo o monopólio da terra, a família de tipo patriarcal havia crescido "a ponto de atrofiar as demais esferas da vida social" (Idem, p. 130). Embora a dominação exercida pelas famílias senhoriais estivesse em decadência desde fins do século XIX, sua centralidade na formação social do país havia produzido efeitos duradouros no plano da cultura, traduzindo-se em padróes de comportamento altamente pessoalizados na esfera pública, que entravavam a "maturidade política" da nação (Idem, p. 134). Rios pondera que somente o "desenvolvimento harmonioso" da família, articulado ao de instituições igualmente relevantes, como a escola e a igreja, podia garantir o "florescimento de comunidades equilibradas [e evitar] a hipertrofia monstruosa do Estado", que crescia no vácuo representado pela falta de grupos organizados (Idem, p. 134). Aliada à distribuição de terras, uma "reforma educacional" devia incidir sobre o fortalecimento das associações locais, estimulando a participação de suas lideranças (Rios, 1950b). Contra a "mentalidade estatolátrica” das classes dirigentes, era preciso favorecer a participação dos municípios na implementação das políticas públicas (1948d).

Rios vislumbrou a possibilidade de levar a cabo sua proposta de sociologia aplicada ao coordenar, em seus primeiros anos, a Campanha Nacional de 
Educação Rural do Departamento Nacional de Educação (CNER), da qual foi um dos principais idealizadores. Na esteira dos programas de educação de base da Unesco, Rios propôs ao governo uma política destinada à "tarefa da autoeducação" (Rios, 1951, p. 16), que consistia em impulsionar o homem do campo, pela "emulação criadora" (Idem), a vencer a apatia e a tomar parte em iniciativas comunitárias destinadas à elevaçáo dos seus padrōes de vida. $\mathrm{O}$ sociólogo enfatiza a importância dessas medidas no contexto brasileiro nos primeiros relatórios enviados ao Departamento Nacional de Educação:

O senso comunitário tem de ser despertado num povo de individualistas. [...] o educador tem de escolher técnicas educativas que deem aos homens do meio rural a noçáo da própria valia, juntamente com o sentimento de independência e o senso de responsabilidade, sem o que náo se constroem povos, mas somente massas submissas (Idem, p. 17).

Em 1954, Rios publica A educação dos grupos, livro que reflete, além de suas experiências em educação rural, as atividades desenvolvidas no Serviço Especial de Saúde Pública (Sesp) a partir de 1953, como chefe da Seção de Pesquisas Sociais da Divisão de Educação Sanitária. Resultado da compilaçáo de aulas que ministrou a técnicos e auxiliares de educação sanitária, o texto apresenta um conjunto de técnicas e conselhos práticos ligados à organização de comunidades rurais e é peça-chave na compreensão de sua perspectiva sociológica. Agir por meio dos grupos, que, como a família, a escola, a igreja e a vizinhança, exerciam ascendência sobre o indivíduo, seria a melhor maneira de alterar hábitos e crenças considerados nocivos e atrasados, promovendo a mudança cultural. Os cientistas sociais deveriam atuar como mediadores ou intérpretes, traduzindo, para o sistema de valores nativo, os traços culturais que os agentes públicos buscavam difundir (Maio e Lima, 2009). ${ }^{25}$ A efetividade das políticas do Estado não seria garantida por açôes verticalizadas do poder público, mas exigia que a mudança transcorresse desde dentro, mediante a incorporação gradual, pela comunidade, de práticas e concepçóes modernas de saúde e trabalho. As li- deranças locais, uma vez identificadas, deveriam ser estimuladas a participar das atividades de planejamento e intervençáo, servindo como focos irradiadores de mudança. ${ }^{26}$

O setor de educação sanitária do Sesp aderiu a sugestôes de Rios, experimentando ações educativas em que as populaçôes locais se envolviam diretamente com os programas de saúde, como foi o caso da construçáo de um posto de saúde em Banco de Vitória, bairro do município de Ilhéus, por uma comissão de melhoramentos formada por moradores da localidade em 1954 (Sesp, 1954a, p. 107). As demais divisóes do órgão também desenvolveram açóes imbuídas do espírito participativo, a exemplo da Divisão de Engenharia Sanitária, que levou a cabo programas de habitaçáo popular e obras de infraestrutura sanitária com base no princípio da ajuda mútua, em que a populaçáo beneficiada ou financiava parte dos custos ou emprestava sua própria força de trabalho à realização da tarefa (Sesp, 1954b, pp. 27-28).

A argumentação de Rios em prol da ação das comunidades repercute os embates ideológicos acerca do fenômeno do totalitarismo. As comunidades serviriam de contrapeso às forças políticas centralizadoras e burocratizantes que assediavam o mundo moderno (Rios, 1954, p. 8). A sobrevivência das democracias dependeria de modelos de intervenção social que suscitassem no homem comum o "senso das responsabilidades sociais e dos deveres com o próximo", de modo que ele fosse estimulado a participar dos programas e das decisóes políticas ligadas ao destino das coletividades (Idem, p. 27). Este é o sentido da literatura norte-americana sobre "planejamento democrático" que atravessa seu livro, apresentada como alternativa aos modelos fascista e soviético de engenharia social. ${ }^{27}$ Dentre essas referências, destaca-se o texto de David Lilienthal, publicado em fins da Segunda Guerra e intitulado sugestivamente TVA, Democracy on the march, uma avaliaçáo do programa de integraçáo regional e desenvolvimento econômico do Vale do Tennessee conduzido pelo Governo Roosevelt nos anos de 1930 (Idem, pp. 239-240). A perspectiva de Rios também converge com os princípios de cooperação e harmonia social que orientaram a atuação do clero católico brasileiro em torno de soluçôes con- 
ciliatórias e não disruptivas para os conflitos que se acirravam no campo em torno da posse da terra em meio ao crescimento das organizaçóes e movimentos de trabalhadores rurais (Barreiro, 2010). Com efeito, o sociólogo valorizou, nos primórdios da CNER, a articulação dos seus serviços com ações que vinham sendo realizadas por lideranças católicas, como o serviço de assistência rural dirigido pelo então vigário Eugenio Salles no Rio Grande do Norte, ${ }^{28}$ e por particulares, como o centro de formação de professoras rurais instalado por Helena Antipoff na Fazenda do Rosário, em Minas Gerais.

Em A educação dos grupos, Rios também explora de maneira mais sistemática as implicaçôes do conceito sociológico de comunidade para os programas de saúde e educação rural. Conferindo pioneirismo aos estudos de Charles Galpin, que desenvolvera uma metodologia capaz de identificar os contornos precisos das comunidades rurais nos Estados Unidos, Rios apresenta uma história do conceito de comunidade no quarto capítulo do livro, passando em revista trabalhos que se desenvolveram nos campos da sociologia rural, da antropologia e da ecologia humana. São mencionados estudos então considerados clássicos, a exemplo de Middletown, de Robert e Helen Lynd (1929); Community, a sociological study, de R. MacIver (1936); The status systems of a modern community, de Lloyd Warner e Paul Lunt (1942), além das pesquisas urbanas inspiradas na abordagem ecológica do sociólogo de Chicago Robert Park. As pesquisas que Donald Pierson e Emílio Willems haviam conduzido no interior de São Paulo são referidas como marcos no desenvolvimento dos estudos de comunidade no Brasil ao lado dos estudos de T. Lynn Smith sobre os grupos de localidade do país.

A definição de Rios de comunidade converge com a de T. Lynn Smith. Ela se aplica a todo tipo de agrupamento humano vivendo em contiguidade especial, marcado pela proximidade dos contatos, por relaçôes face a face, fortes consensos valorativos e identidade de grupo (Rios, 1954, p. 80). Esta ideia de comunidade, todavia, é posta em tensão ao longo do livro, e a homogeneidade sociocultural e o consenso pressupostos pelo conceito perdem terreno para a complexidade empírica das referências a municípios e zonas rurais específicas do Brasil, marcadas por cisóes de classe e cultura que Rios atribui à preponderância do latifúndio. Havia "barreiras sociais" que se traduziam em estereótipos de classe:

O "superior" pensa nas camadas mais baixas compostas de "vagabundos", "cachaceiros", "interesseiros", etc., e procura pautar suas relaçóes de acordo com tais critérios. Por sua vez, as classes inferiores olham com grande desconfiança para as de categoria mais alta, porque sempre as consideram como "patróes", isto é, como pessoas que procuram tirar do "povo" o máximo proveito possível (Idem, pp. 64-65).

Há passagens do texto que permitem entrever as experiências de conflito envolvendo latifundiários, trabalhadores rurais e posseiros que vinham se acumulando desde os anos de 1940: "Os focos de eclosão revolucionária que periodicamente aparecem, como nos casos recentes do Norte do Paraná e do Oeste Paulista, não tardarão a se repetir" (Idem, p. 192).

Rios se aproxima do diagnóstico de Smith sobre a vida social nas comunidades rurais brasileiras ao abordar os problemas que impediam o seu pleno desenvolvimento em unidades sociais integradas. Endossando a tese do insolidarismo, ele enxerga na educação dos grupos e na organização de comunidades náo apenas o meio para introduzir a mudança cultural, mas também o estímulo a formas de associação que superassem a passividade e o desinteresse característicos, a seu ver, do povo brasileiro perante as açóes do poder público. No livro, Rios torna a insistir, ademais, que as intervençôes em educação e saúde deviam estar articuladas a um amplo programa de reforma agrária (Maio e Lopes, 2012). As cisôes de classe reproduzidas pelo acesso restrito à terra constituíam um óbice à transformação dos municípios em comunidades integradas, marcadas pela contínua circulação de bens e pessoas, pela frequência e proximidade dos contatos e pela ampla participação política de seus membros.

A análise da proposta de intervenção social de Rios evidencia que o conceito de comunidade, uma das categorias cardinais de sua sociologia, é investido de forte carga valorativa. Além de buscar descrever ou explicar a realidade social brasileira, ele é indicativo de um ideal de organização social cujas 
marcas são a cooperação e a ampla participação política. Trata-se de um modelo de sociedade que supóe forte associativismo local, base de um sistema político em que os problemas e os conflitos são geridos pelo "maior número possível de indivíduos, que por sua vez estáo capacitados a participar direta ou indiretamente do poder e do seu controle pela opiniāo pública visando ao bem comum" (Rios, 1954, p. 23). A comunidade é concebida, idealmente, como "matriz de civilização", ou ainda, como "forma social de inserção do homem na paisagem e um tipo superior de convivência" em que este pode desenvolver plenamente sua personalidade (Idem, p. 87).

\section{Sociologia rural, democracia e matriz autoritária de pensamento}

As sociologias de T. Lynn Smith e José Arthur Rios convergem, em seus pontos essenciais, na avaliação dos obstáculos à modernização da sociedade brasileira e à consolidação de um regime político democrático no país: o uso disseminado de técnicas primitivas de agricultura de origem indígena, o isolamento e a dispersão das populaçóes pelo território nacional, a falta de vínculos das famílias e das vizinhanças à vida comunitária local, o particularismo das condutas, a passividade e a falta de iniciativa do homem rural e, sobretudo, a instituição do latifúndio, responsável pelo abismo social entre as classes e pelo predomínio de relaçóes de tipo paternalista no campo.

$\mathrm{Na}$ perspectiva de ambos os sociólogos, as condições de vida das populaçôes rurais deviam ser alvo de um amplo e intrincado programa de engenharia social e reforma agrária. Mecanismos de taxação progressiva da propriedade fundiária, políticas de colonização destinadas à fixação de fazendas familiares e a organização de serviços de educação e saúde em bases municipais, estimulando a participação das populaçôes e governos locais na solução de seus problemas, viriam a desencadear a mudança social necessária. Tratava-se de garantir a propriedade da terra ao pequeno agricultor e difundir práticas modernas de saúde, trabalho e consumo de modo a transformar matutos e caboclos em uma classe média de fazendeiros aptos a exercer as funçóes de empreendedor, administrador e trabalhador. Nos primórdios da Guerra Fria, o combate ao latifúndio foi considerado medida prioritária para estes sociólogos, que enxergavam no quadro de desigualdades sociais, característico das zonas rurais brasileiras, terreno propício para o avanço do comunismo.

Marcados por compromissos político-normativos evidentes, Smith e Rios tenderam a reivindicar, não obstante, a aplicabilidade de uma ciência social que se pretendia axiologicamente neutra a fim de tentar garantir, em um cenário global de polarização ideológica, formas de atuação para os sociólogos no mundo das políticas públicas que, ao mesmo tempo, preservassem o almejado caráter científico de seu trabalho. Nos textos aqui analisados, ambos parecem conceber, a partir de uma perspectiva dicotômica também presente em obras clássicas de sociólogos norte-americanos que se debruçaram sobre o problema do conhecimento aplicado, a exemplo de Henry P. Fairchild (1916), a pesquisa aplicada como etapa dissociada, e mesmo deriva$\mathrm{da}$, em relação à pesquisa fundamental. No caso de Rios, essa visão está afinada com o trabalho, que buscou desempenhar, de divulgação do arcabouço teórico e metodológico das ciências sociais entre os profissionais de educação e saúde da CNER e do Sesp, consubstanciado em $A$ educação dos grupos. ${ }^{29}$

Para refletir sobre os desafios práticos postos à modernização brasileira, as sociologias de Smith e Rios retomam as linhas de reflexão desenvolvidas por autores do pensamento social no Brasil que acentuaram o caráter amorfo, desarticulado, de sua sociedade, indicando com isso a ausência de formas associativas entre indivíduos e grupos para além dos estreitos laços de solidariedade no interior das famílias. As teses de Oliveira Vianna em Populaçóes meridionais do Brasil, sublinhando o papel simplificador do latifúndio sobre a estrutura social do país e a ausência de laços de solidariedade social para além dos círculos familiares e parentais, forneceram coordenadas intelectuais fundamentais para as leituras que Smith e Rios operaram da realidade brasileira, repercutindo até mesmo sobre a avaliação de ambos acerca da importância estratégica da reforma agrária e da educação dos grupos de base das comunidades rurais como medidas capazes de conduzir ao reordenamento da sociedade como um todo. Do 
conjunto de textos de Oliveira Vianna, a interpretação do país contida em Populaçóes meridionais do Brasil constitui a principal referência nos trabalhos daqueles sociólogos.

A força cognitiva dessa matriz de pensamento ${ }^{30}$ nas sociologias de Smith e Rios torna-se ainda mais evidente se considerarmos que, a despeito de terem confirmado, em suas linhas gerais, a visão de Oliveira Vianna sobre a formação social brasileira, ambos divergiram dos apontamentos deste último quanto aos meios tendentes à instauração de uma nova ordem social no país. Isto é, enquanto as formulaçóes de Vianna redundaram no elogio do Estado forte e centralizado nas máos do Executivo, único agente que teria sido capaz, no Império, de fazer frente às forças centrífugas das oligarquias rurais, promovendo a unidade nacional e a supremacia da lei e da ordem em um mundo de arbitrariedades e lutas facciosas, ${ }^{31}$ as apostas de Smith e Rios para a efetivação do mundo dos direitos no Brasil residiram no fortalecimento de instituiçóes locais como a escola, a igreja e as associaçóes de bairro, na descentralização do poder político e na ampliação do acesso à propriedade da terra, tendo em vista a formação de uma pujante sociedade civil, de comunidades politicamente ativas. Esses são os elementos que os distanciam do encaminhamento político dado por Oliveira Vianna ao insolidarismo, seja este entendido como expressão de uma tradição de "autoritarismo instrumental" visando à promoção da ordem liberal burguesa no Brasil (Santos, 1978), seja como projeto de uma Ibéria renovada, organizada hierarquicamente conforme princípios organicistas (Vianna, [1997] 2004).

Partindo do diagnóstico de Oliveira Vianna dos males nacionais, que assinalava suas origens rurais, as sociologias de Smith e Rios optaram, todavia, por soluçáo diversa, buscando, em lugar do fortalecimento do Estado e da concentração de poderes nas mãos do Executivo, a viabilização das condiçôes sociais para a emergência das camadas subalternas, do povo como ator político autônomo na história brasileira, questão que perpassou, guardadas as diferenças de ordem teórico-metodológica, a sociologia produzida no Brasil dos anos de 1950, como é possível observar nos estudos de autores como Nestor Duarte, Evaristo de Moraes Filho, Florestan Fernandes, Maria
Isaura Pereira de Queiroz e Maria Sylvia de Carvalho Franco (Dombrowski, 2000; Villas Bôas, 2004; Brasil Jr. e Botelho, 2016). Certamente que o Estado tinha papéis a desempenhar nas propostas de intervenção social de Smith e Rios, mas esses consistiam, sobretudo, em ações do poder local em articulação com as comunidades.

Nos escritos de Smith e Rios, a centralidade assumida pela comunidade como categoria sociológica permite entrever o horizonte político-normativo comum a ambos, em que se delineia um modelo de sociedade fundado nos princípios da cooperação social e do autogoverno. Ainda assim, ao prescreverem uma reforma agrária que conferisse corpo a robustas classes médias rurais, não fizeram senão explorar a proposição contida em Populaçóes meridionais do Brasil, segundo a qual a cultura cívica do Ocidente havia germinado em contextos sociais marcados pelo regime da pequena propriedade (Oliveira Vianna, [1920] 1938, p. 169), proposição da qual Oliveira Vianna, todavia, não extraiu orientações específicas para o plano da ação prático-política (Chaguri e Bastos, 2015). Mesmo em textos posteriores, como Instituiçôes políticas brasileiras, escrito no pós-Estado Novo, em plena redemocratização do país, Vianna, apesar de retomar a relação entre cidadania política e propriedade da terra, reafirmando a inexistência de um "sistema de pequena propriedade largamente difundido" no Brasil capaz de assegurar "um eleitorado consciente, capaz e livre" (Oliveira Vianna, 1949, p. 222), revela-se mais preocupado em indicar a necessidade de reformas institucionais centralizadoras, especialmente no âmbito da justiça, visando ao controle dos efeitos do "espírito de clä" na vida pública e à garantia dos direitos civis. Em nítida referência à Constituição de 1946, ele reitera suas conhecidas críticas à incongruência entre o contexto social brasileiro e os ideais políticos que, a seu ver, animavam persistentemente as classes dirigentes do país, como os princípios do sufrágio universal e do municipalismo.

O papel que tradições intelectuais brasileiras desempenharam na elaboração das visões de Smith e Rios sobre o Brasil, por sua vez vinculados a correntes da sociologia rural dos Estados Unidos, convida-nos a repensar o sentido usual atribuído aos fluxos de ideias entre o Norte e o Sul globais, 
pondo em relevo, em que pesem as assimetrias de poder, o caráter transnacional da produção sociológica do passado. Em vez de se defrontar, sem mediaçóes, com uma suposta realidade empírica pura, ambos se valeram de interpretaçóes produzidas por intelectuais do país no esforço de conferir inteligibilidade à sociedade brasileira. Note-se, ademais, que o peso adquirido pela obra de Oliveira Vianna, em especial Populaçóes meridionais do Brasil, nas leituras de Smith e Rios se torna compreensível quando se consideram as fortes afinidades teóricas entre tradiçóes brasileiras e norte-americanas de conhecimento que, embora gestadas em distintos contextos nacionais, destacavam, igualmente, no plano explicativo, as relaçóes entre estrutura fundiária, dinâmica societária e exercício do poder político.

\section{Consideraçóes finais}

Por operarem, na elaboração do diagnóstico dos problemas da sociedade brasileira, no interior de matriz de pensamento que remonta a Oliveira Vianna e, não obstante, oporem-se às soluçóes autoritárias e estatizantes que aquela tendeu a justificar, as sociologias de T. Lynn Smith e José Arthur Rios se veem, por vezes, diante de impasses que decorrem da própria situação, por eles identificada, de uma sociedade civil invertebrada coexistindo com um Estado acachapante e orientado pela lógica particularista. No caso de Smith, o paradoxo parece residir no fato de que o papel destacado que confere aos municípios, que deveriam ser dotados de maior capacidade tributária, especialmente com base na taxação de terras, a fim de poderem implementar políticas visando à melhoria das condiçôes da vida local, supunha, de antemão, a existência de uma comunidade de cidadãos ativos aptos a controlar a adequada utilização dos recursos públicos. Tal comunidade, no entanto, seria corolário, e não causa, da reforma agrária. Smith estava ciente de que, tradicionalmente, as instituiçóes municipais haviam sido instrumentalizadas por "chefetes locais" (Smith, 1946, p. 742), capítulo conhecido da história social e política brasileira escrita por Vianna (Oliveira Vianna, [1920] 1938). Ainda que o desenvolvimento das cidades tivesse alterado li- geiramente essa situação, Smith reconhecia que as populações rurais permaneciam em grande medida dispersas, isoladas, a mercê dos grandes fazendeiros e fora do raio de alcance da autoridade pública (Smith, 1946, p. 773). Nesse sentido, parece bastante otimista a aposta do sociólogo norte-americano de que as câmaras e as prefeituras viessem a ser, com o tempo, o lugar por excelência da participação e do controle cidadãos em substituição às práticas rotineiras de dominação pessoal e apropriação privada da coisa pública.

Rios, por seu turno, desde o início da década de 1950 , acrescentou notas pessimistas ao programa da reforma agrária, constatando a ausência de atores no cenário social brasileiro que pudessem levá-la a efeito. As ramificaçôes do latifúndio no mundo da política e nos órgãos do Estado tornavam improvável que a redistribuição de terras com base em fazendas familiares partisse das classes dirigentes, cujos quadros eram dominados por "interesses baseados na posse da terra ou da indústria, os continuadores da política dos latifundiários através dos tempos" (Rios, 1950b). Por outro lado, dada a ausência crônica do povo, de grupos sociais subalternos organizados em torno de interesses comuns e aptos a exercer pressão reivindicatória, dificilmente a reforma poderia ser empreendida pelas "forças sociais interessadas" em sua implementação, isto é, as massas rurais, que vegetavam em um "regime de semiescravidão", e os sindicatos urbanos, que permaneciam na "camisa de força do peleguismo e da tutela estatal" (Rios, 1959). Longe de se traduzirem em mudanças substantivas, as alteraçóes em curso na sociedade brasileira, como o aumento da população urbana e a maior integração inter-regional promovida pela ampliação da malha rodoviária do país, não sendo acompanhadas da reforma das estruturas sociais do campo, haviam culminado no crescimento desordenado das cidades, com as favelas recebendo os segmentos sociais empobrecidos que migravam em busca de melhores condiçóes de vida. Tratava-se de modernização vertiginosa, porém reprodutora das desigualdades, em que a antiga "ordem social paternalista" se transmutava em um "tipo de sociedade demo-paternal", de massas passivas e sujeitas ao controle do Estado e dos partidos políticos (Rios, 1956, p. 8). Em 1959, diante 
desse quadro, Rios conclui, não sem pessimismo, que a "grande indústria e as forças armadas", caso tomassem consciência de seus reais interesses, ligados, respectivamente, ao fortalecimento do mercado interno e ao imperativo de segurança nacional, poderiam pressionar o poder público a promover as reformas necessárias. Desacreditados os "movimentos de massa”, transformaçóes sociais significativas no país pareciam, a seu ver, estar destinadas a provir de "movimentos de cúpula", como fora o caso da Abolição (Rios, 1959). Ainda que recuse as soluçóes estatizantes de corte autoritário, ao modo de Oliveira Vianna, sua sociologia acabou por apostar em mudanças pelo alto em se tratando do processo de reordenamento da sociedade.

\section{Notas}

1 O modelo difusionista, em sua formulação clássica, encontra-se em Basalla (1967). Para uma crítica a esta visão, que considera a circulaçáo transnacional como dimensão constitutiva da produção do conhecimento científico, ver Raj (2007).

2 Para um estudo da emergência da modernidade como processo histórico global, e não exclusivamente europeu, ver Chakrabarty (2000). Uma análise sobre as implicaçôes do debate pós-colonial para a teoria social encontra-se em Costa (2006).

3 Peixoto ([1989] 2001) analisa a presença de cientistas sociais norte-americanos no Brasil no período de institucionalização das ciências sociais no país, sem mencionar, todavia, as atividades de Smith.

4 Lima (1999) aborda as continuidades, no plano cognitivo, entre o pensamento social brasileiro e as pesquisas sobre o mundo rural desenvolvidas por Emílio Willems, Antonio Candido e Maria Isaura Pereira de Queiroz.

5 Informação extraída da entrevista de Louvina Smith, esposa do sociólogo, concedida a Emily Ring em 5/3/1979. "Mrs. Lynn Smith". University of Florida Oral History Collections. Disponível em http:// ufdc.ufl.edu/UF00006017/00001, consultado em $1 / 12 / 2015$.

6 Carta de Smith a Arthur Ramos, 6/2/1944. Arquivo Arthur Ramos - Seção de Manuscritos (Biblioteca Nacional).

7 O sociólogo Robert Park, da Universidade de Chicago, nutria especial interesse pelo tema das relaçóes interétnicas nos Estados Unidos e, no final de sua carreira, buscou desenvolver uma abordagem comparativa das diferentes situaçóes raciais existentes ao redor do mundo a partir de viagens feitas a diversos países, incluindo o Brasil. Ver Valladares (2010).

8 A convite de Smith, e com fundos da General Education Board da Fundação Rockefeller, Arthur Ramos lecionou na Universidade Estadual de Louisiana entre 1940 e 1941, sendo responsável por um curso sobre relaçóes raciais e por um seminário sobre raça e cultura no Brasil.

9 Os sociólogos rurais que viajaram em missão oficial do governo norte-americano pela América Latina no período foram: Carl Taylor (Argentina); Nathan Whetten (México); Lowry Nelson (Cuba); Charles Loomis (Peru, El Salvador e México) (Smith e Montiel, 1958).

10 A serviço do Departamento de Estado, Smith também atuou como consultor técnico do governo colombiano em meados da década de 1940. Ver Cronshaw (1982) e Lorek (2013).

11 "Sociólogo americano falará sobre reforma agrária”. Correio da Manhã, 1o Caderno, 17 de julho de 1956, pp. 3 e 11 .

12 Essa tipologia da organização social rural remonta aos trabalhos de Pitrim Sorokin, Carle Zimmerman e Charles Galpin, mais particularmente, ao manual organizado por esses autores, $A$ sistematic source book in rural sociology (1930).

13 Smith não foi o único a retomar a obra de Oliveira Vianna. Sobre os desdobramentos desta em pesquisas sociológicas posteriores à institucionalização universitária das ciências sociais no Brasil, ver Villas Bôas (2004) e Botelho (2010, 2012).

14 Rios se converteu ao catolicismo por influência da esposa, Regina Alves de Figueiredo, que conhecera no curso de ciências sociais. Regina era filha de Jackson de Figueiredo, expressiva liderança intelectual católica e fundador do Centro Dom Vital.

15 Informações sobre a trajetória intelectual de José Arthur Rios foram extraídas de Rios (2000, 2006).

16 Sobre as intervenções da Resistência Democrática no debate público, ver Dulles (2001).

17 Sternberg foi o primeiro brasileiro que, por intermédio de Smith, realizou pós-graduação nos Estados Unidos, cursando geografia na Universidade Estadual de Louisiana. Além de Rios, estudaram com Smith nos Estados Unidos, entre outros, Freitas Marcondes e João Gonçalves de Souza (Smith, 1974). 
18 Sobre a CNER, ver Barreiro (2010).

19 Sobre o Sesp, ver Campos (2006). Em meados dos anos de 1940, o antropólogo norte-americano Charles Wagley, então à frente da Divisão de Educação Sanitária do Sesp, havia atuado na implementação de programas sanitários na Amazônia (Figueiredo, 2009).

20 No jogo de contrastes entre Estados Unidos e Brasil, importava, sobretudo, destacar a cultura democrática do primeiro, o que explica por que a segregaçáo racial no Sul náo foi tema destes artigos de Rios, ainda que tenha lhe chamado a atenção (Rios, 2006).

21 Apostas quanto à relevância da sociologia, tal como praticada nos Estados Unidos, para a soluçáo dos "problemas sociais" do Brasil haviam sido expressas por Rios em 1945, em carta dirigida ao sociólogo norte-americano Donald Pierson, professor da Escola de Sociologia e Política de São Paulo, meses antes de sua viagem a Louisiana. Carta de José Arthur Rios para Donald Pierson, 30/9/1945. Arquivo Edgard Leuenroth - Fundo Donald Pierson (Unicamp).

22 Entre os estudiosos cujos modelos de pesquisa poderiam orientar a ação do poder público, Rios menciona, nos campos da sociologia e da antropologia, T. Lynn Smith, Donald Pierson, Charles Wagley, Kalervo Oberg Tales de Azevedo, além dos geógrafos Orlando Valverde e Leo Waibel. Cf. Campanha Nacional de Educação Rural, "Identificação dos métodos a adotar para a educação do povo". Revista da CNER, Ministério da Educação e Cultura, ano 7, n. 9, 19591960 , p.17.

23 Ver Maio e Lopes (2012). Ao menos no que concerne à criação da Escola de Sociologia e Política de São Paulo, como sugerem Del Vecchio e Diéguez (2008), que analisaram as pesquisas de Horace Davis e Samuel Lowrie sobre o padráo de vida do operariado paulistano, pode-se afirmar que o interesse pela aplicação do conhecimento, principalmente por parte das elites modernizantes daquele Estado, foi constitutivo da institucionalização da sociologia.

24 A interlocução de Rios, na área da saúde, com a sociologia de Guerreiro Ramos, orientada explicitamente por um projeto político de construção nacional, é elemento igualmente relevante para a compreensão de sua visão acerca dos papeis a serem desempenhados pelos cientistas sociais (Maio e Lopes, 2012).

25 A aplicabilidade das ciências sociais em saúde pública foi uma constante dos textos publicados por Rios no Boletim do SESP (Rios, 1953a, 1953b, 1953c).

26 Nas palavras do sociólogo: "A participação [...], em qualquer tipo de planejamento que interesse seus há- bitos, neutraliza a atitude natural de hostilidade ou de indiferença do indivíduo perante o novo traço" (Rios, 1954, p. 51).

27 É o caso, por exemplo, de Rural community organization (1939), de Dwight Sanderson e Robert Polson; The small community looks ahead (1947), de Wayland Hayes; e Organizing for community action (1948), de Clarence King.

28 Otto Guerra, "Formação de líderes rurais. O Serviço de Assistência Rural - Reunióes de párocos - As Semanas Rurais - Cursos intensivos - Centro de Treinamento de Professores - Fala-nos o Cônego Eugênio Salles". A Ordem, 19 out. 1952, pp. 3-4.

29 No Brasil, uma reflexão teórica sistemática sobre a sociologia aplicada será conduzida por Florestan Fernandes a partir de sua atividade docente na Universidade de São Paulo. Fernandes buscará rever o entendimento tradicional acerca das relaçóes entre pesquisas fundamental e aplicada, destacando o valor da última não apenas para a ação prática, mas também para o próprio refinamento teórico do conhecimento sociológico denominado básico (Fernandes, 1960). Buscava, ao que tudo indica, legitimar as vinculaçóes crescentes entre cientistas sociais e as atividades de planejamento governamental não somente para o público em geral, mas no âmbito da própria ciência.

30 Empregamos o termo à maneira do estilo de pensamento de Fleck (2010): conjunto de disposições intelectuais inter-relacionadas, historicamente contingente e de natureza coletiva que tem por função cognitiva ordenar a experiência do mundo, tornando-a significativa.

31 É a falta de condiçôes para o exercício de direitos civis e políticos que parece ser o objeto da crítica do autor de Populaçóes meridionais no Brasil ao analisar os efeitos duradouros da solidariedade clânica na "psicologia do homem do povo" (Oliveira Vianna, [1920] 1938, p. 201).

\section{BIBLIOGRAFIA}

BARREIRO, Iraíde Marques de Freitas. (2010), Politica de educaçáo no campo: para além da alfabetização. São Paulo, Cultura Acadêmica.

BASALLA, George. (1967), "The spread of Western science". Science, 156: 611-622.

BIELCHOWSKY, Ricardo. (1995), Pensamento econômico brasileiro: o ciclo ideológico do desenvolvimentismo. 2 ed. Rio de Janeiro, Contraponto. 
BOTELHO, André. (2010), "Passado e futuro das interpretaçōes do país”. Tempo Social, 22, 1: 47-66.

(2012), "Interpretações do Brasil e ciências sociais, um fio de Ariadne”. Sinais Sociais, 7 (20): 10-35.

BIZZO, Maria Letícia Galluzzi. (2009), "Ação política e pensamento social em Josué de Castro". Boletim do Museu Paranaense Emílio GoeldiCiências Humanas, 4 (3): 401-420.

BRASIL JR., Antonio S. (2011), Passagens para a teoria sociológica: Florestan Fernandes e Gino Germani. Rio de Janeiro, tese de doutorado em sociologia, Instituto de Filosofia e Ciências Sociais, Universidade Federal do Rio de Janeiro.

BRASIL JR., Antonio \& BOTELHO, André. (2016), "Passagens do rural ao urbano e participação social: a sociologia política brasileira dos anos de 1960". Cadernos CRH, 29 (77): 209-227.

CAMIC, Charles. (2007), "On the edge: sociology during the great depression and the New Deal", in Craig Calhoun (org.), Sociology in America: a history, Chicago, The University of Chicago Press, pp. 225-280.

CAMPOS, André. (2006), Politicas internacionais de saúde na era Vargas: o Serviço Especial de Saúde Pública, 1942-1960. Rio de Janeiro, Fiocruz.

CHAGURI, Mariana Miggiolaro \& BASTOS, Elide Rugai. (2015), “A atualidade do rural”. Lua Nova, 95: 13-26.

CHAKRABARTY, Dipesh. (2000), Provincializing Europe: postcolonial thought and historical difference. Princeton, University of Princeton.

CORREIO da Manhã. (1952), "Autonomia". Correio da Manhã, 18 set. (1 Caderno).

COSTA, Sergio. (2006), "Desprovincializando a sociologia: a contribuição pós-colonial”. Revista Brasileira de Ciências Sociais, 21 (60): 118183.

COSTA LIMA, Marcos. (2011), Região e desenvolvimento no capitalismo contemporâneo: uma interpretação crítica. São Paulo, Cultura Acadêmica.

CRONSHAW, Francine. (1982), "Exporting ideology: T. Lynn Smith in Colombia”. NS, 7 (13): 95-109.
DEL VECCHIO, A. \& DIÉGUEZ, C. (2008), "As pesquisas sobre o padrão de vida dos operários da cidade de São Paulo e a institucionalização da sociologia no Brasil”, in ___ (orgs.), As pesquisas sobre padráo de vida dos trabalhadores da cidade de São Paulo - Horace Davis e Samuel Lowrie: pioneiros da sociologia aplicada no Brasil. São Paulo, Sociologia e Política.

DOMBROWSKI, Osmir. (2000), “Ordem privada e reforma agrária em Nestor Duarte". Lua Nova, 49: 225-255.

DULLES, J. W. (2001), Sobral Pinto: a consciência do Brasil - A cruzada contra o regime Vargas, 1930-1945. Rio de Janeiro, Nova Fronteira.

ESCOBAR, Arturo. (1996), La invención del tercer mundo: construcción y deconstrucción del desarollo. Santa Fé de Bogotá, Norma.

FAIRCHILD, Henry Pratt. (1916), "Part I: introduction", in , Outline of applied sociology, Nova York, The Macmillan Company, pp. $1-43$.

FERNANDES, Florestan. (1960). Ensaios de sociologia geral e aplicada. São Paulo, Pioneira.

FIGUEIREDO, Regina Érika Domingos de. (2009), Histórias de uma antropologia da "boa vizinhança": um estudo sobre o papel dos antropólogos nos programas interamericanos de assistência técnica e saúde no Brasil e no México (1942-1960). Campinas, tese de doutorado, Universidade Estadual de Campinas (Unicamp).

FLECK, Ludwik. (2010), A gênese e o desenvolvimento do fato cientifico. Belo Horizonte, Fabrefactum.

HEILBRON, J.; GUILHOT, N. \& JEANPIERRE, L. (2008), "Toward a transnational history of the social sciences". Journal of The History of the Behavioral Sciences, 44 (2): 146-160.

LAZARSFELD, Paul F. \& REITZ, Jeffrey G. (1989), "History of applied sociology". Sociological Practice, 7 (1): 43-52.

LEAL, Carlos Eduardo de Casto \& FLAKSMAN, Dora. (1984), "Partido Libertador (19451965)". Rio de Janeiro, FGV/CPDOC (verbete). Disponível em http://www.fgv.br/cpdoc/ acervo/dicionarios/verbete-tematico/partido-libertador-pl-1945-1965, consultado em 18/7/2016. 
LIMA, Nísia Trindade. (1999), Um sertão chamado Brasil: intelectuais e representação geográfica da identidade nacional. Rio de Janeiro, tese de doutorado, Iuperj.

LOOMIS, Charles. (1942), "Applied anthropology in Latin America". Applied Anthropology, 2 (1): 37-39.

LOREK, Timothy W. (2013), "Imagining the Midwest in Latin America: US Advisors and the envisioning of an agricultural middle class in Colombia's Cauca Valley, 1943-1946". The Historian, 5 (2): 283-305.

MAIA, Joâo Marcelo E. (2011), "Ao sul da teoria: a atualidade teórica do pensamento social brasileiro". Sociedade e Estado, 26 (2): 71-94.

MAIO, Marcos Chor. (1997). A história do projeto Unesco: estudos raciais e ciências sociais no Brasil. Rio de Janeiro, tese de doutorado em ciência política, Iuperj.

MAIO, Marcos Chor \& LIMA, Nísia Trindade. (2009), "Tradutores, intérpretes ou promotores de mudança? Cientistas sociais, educação sanitária rural e resistências culturais (194060)". Sociedade e Estado, 24 (2): 529-561.

MAIO, Marcos Chor \& LOPES, Thiago da Costa. (2012), "Da Escola de Chicago ao nacional-desenvolvimentismo: saúde e nação no pensamento de Alberto Guerreiro Ramos". Sociologias, 14 (30): 290-329.

OLIVEIRA VIANNA, Francisco José de. ([1920] 1938), Populaçôes meridionais do Brasil. 4 ed. São Paulo, Companhia Nacional.

. (1949), Instituiçóes politicas brasileiras.

Rio de Janeiro, José Olympio, vol. 2.

PEIXOTO, Fernanda Arêas. ([1989] 2001), "Franceses e norte-americanos nas ciências sociais brasileiras, 1930-1960", in S. Miceli (org.), História das ciências sociais no Brasil, 2. ed., São Paulo, Sumaré/Fapesp, vol. 1.

POERNER, Arthur José. (2004), O poder jovem: história da participação politica dos estudantes brasileiros. 5 ed. Rio de Janeiro, Booklink.

RAJ, Kapil. (2007), Relocating modern science: circulation and the construction of Knowledge in South Asia and Europe, 1650-1900. Houndmills/Nova York, Palgrave Macmillan.

RIOS, José Arthur. (1946a), "A democracia também se aprende nas escolas". O Globo, 13 maio (2a seção). (1946b), "Só a ONU seria digna de receber o segredo da bomba atômica”. O Globo, 17 jun. (2a seção).

. (1947), "A expansão da sociologia rural no Brasil". A Noite, 19 dez. (entrevista concedida ao jornal $A$ Noite, 1o caderno).

. (1948a), "O castelo de papel e a reforma agrária”. Correio da Manhã, 30 jan. 1948 , p. 4.

. (1948b), "A distribuição de terra e a reforma agrária I". Correio da Manhá, 7 fev. (2o caderno).

(1948c), "A distribuição de terra e a reforma agrária II". Correio da Manhã, 8 fev. (2o caderno).

(1948d), "O pinto e o ovo ou a reforma agrária”. Correio da Manhã, 2 mar., p. 4.

(1950a), "Classe e família no Brasil". Digesto Econômico, 6 (66): 127-134.

. (1950b), "A reforma agrária no Brasil". Tribuna da Imprensa, 8 ago. (Economia).

(1951), "Relatório do coordenador da CNER, professor José Arthur Rios”. Revista da CNER, 7 (9): 16-17.

. (1953a), "A saúde como valor social". Boletim do Sesp, 33: 2-3.

. (1953b), "Informar e convencer". Boletim do Sesp, 35: 5-6.

(1953c), "Ciências sociais e saúde pública”. Boletim do Sesp, 38: 2-3.

. (1954), A educação dos grupos. Rio de Janeiro, Serviço Nacional de Educação Sanitária e Serviço Especial de Saúde Pública do Ministério da Saúde.

(1956), "Forma e sentido da educação rural”. Revista do Serviço Público, 73 (1-3): $1-17$.

(1959). "Reforma agrária: experiência revolucionária, e não uma medida petebista”. Metropolitano, 17 maio (entrevista concedida a César Guimarães, 2o caderno).

. (2000), Resumo de vida. Rio de Janeiro, março (mimeo.).

. (2006), Depoimento. Rio de Janeiro, Casa de Oswaldo Cruz, Fiocruz (entrevista concedida a Nísia Trindade Lima, Marcos Chor Maio e José Leandro Cardoso). 
ROSEMBLATT, Karin. (2014). "Modernization, dependency, and the global in the Mexican critiques of anthropology". Journal of Global History, 9 (1): 94-121.

SANTOS, Wanderley Guilherme dos. (1978), Ordem burguesa e liberalismo político. São Paulo, Duas Cidades.

SAUNIER, Pierre-Yves. (2004), "Circulations, connexions et espaces transnationaux". Genèses, 57: 110-126.

SECORD, James A. (2004), "Knowledge in transit". Isis, 95 (4): 654-672.

SERVIÇO ESPECIAL de Saúde Pública (SESP). (1954A), Relatório. Rio de Janeiro, Ministério da Saúde, jan.-mar.

(1954B), Relatório. Rio de Janeiro, Ministério da Saúde, jul.-dez.

SMITH, T. Lynn. (1934), "An analysis of rural social organization among the French-speaking people of Southern Louisiana”. Journal of Farm Economics, 16 (4): 680-688.

(1935), "The social effects of land division in relationship to a program of land utilization". Journal of Farm Economics, 17 (4): 702-709.

(1937), "Tenure problems and research needs in the South: discussion". Journal of Farm Economics, 19 (1): 143-147.

. (1940), "Trends in community organization and life". American Sociological Review, 5 (3): 325-334.

. (1944), "The locality group structure of Brazil”. American Sociological Review, 9 (1): 41-49.

. (1946), Brazil: people and institutions. Baton Rouge, Louisiana State University Press. . (1947a), "Colonization and settlement in Colombia". Rural Sociology, jun.: 128-139.

. (1947b), "Sistemas agrícolas". Revista Brasileira de Geografia, 9 (2): 159-183.

(1952). "A classe média rural é a espinha dorsal da nação". O Globo, 20 set. (entrevista concedida ao jornal $O$ Globo, $1^{\circ}$ caderno).

. (1959). "The cohesiveness of social systems: a factor of resistance to social change" ["Resistências à mudança: fatores que impedem ou dificultam o desenvolvimento"]. Anais do Seminário Internacional reunido no Rio de
Janeiro, em outubro de 1959. Rio de Janeiro, Centro Latino-Americano de Pesquisas em Ciências Sociais, pp.147-156.

. (1963), "Memorándum: la reforma agraria en Brasil, algunos propósitos y notas breves", in T. Lynn Smith, Sociología rural, Maracaibo, Universidad del Zulia, Faculdad de Agronomia. (1974), "Sociology in Brazil and the United States: some aspects of their interrelationship", in Brazilian society, Albuquerque, Univesity of New Mexico, pp. 3-24.

SMITH, T. Lynn \& MARCHANT, Alexander (orgs.). (1951), Brazil: portrait of half a continent. Nova York, Dryden Press.

SMITH, T. Lynn \& MONTIEL, Ângela Müller. (1958), "La sociología rural en los Estados Unidos de América y en Canadá”. Revista Mexicana de Sociología, 20 (3): 817-842.

SOROKIN, Pitirim; ZIMMERMAN, Carle \& GALPIN, Charles (orgs.). (1930), A systematic source book in rural sociology. Minneapolis, The University of Minnesota Press.

VALLADARES, Lícia do Prado. (2010), “A visita do Robert Park ao Brasil, o 'homem marginal' e a Bahia como laboratório". Caderno CRH, 23 (58): 35-49.

. (2012), "A descoberta do trabalho de campo em 'Aspectos Humanos da Favela Carioca”, in M. A. Mello, L. A. Machado da Silva et al. (orgs.), Favelas cariocas: ontem e hoje, Rio de Janeiro, Garamond.

VIANNA, Luiz Werneck. ([1997] 2004). A revolução passiva: iberismo e americanismo no Brasil. 2 ed. Rio de Janeiro, Revan.

VILLAS BÔAS, Glaucia. (2004), "Evaristo de Moraes Filho e a maioridade dos trabalhadores brasileiros". Revista Brasileira de Ciências Sociais, 19 (55): 19-33.

- (2006a). A recepção da sociologia alemã no Brasil. Rio de Janeiro, Topbooks.

. (2006b), Mudança provocada: passado e futuro no pensamento sociológico brasileiro. Rio de Janeiro, Editora FGV.

WILLEMS, Emílio. (1944), O problema rural brasileiro visto do ponto de vista antropológico. São Paulo, Secretaria de Agricultura, Indústria e Comércio do Estado de São Paulo. 


\section{COMUNIDADE E DEMOCRACIA NA SOCIOLOGIA DE T. LYNN SMITH E JOSÉ ARTHUR RIOS}

\section{Thiago da Costa Lopes e \\ Marcos Chor Maio}

Palavras-chave: A história das ciências sociais; Pensamento social brasileiro; Democracia; Desenvolvimento comunitário; T. Lynn Smith; José Arthur Rios

O artigo investiga, de um ângulo transnacional, a dimensão político-normativa inerente às reflexôes sociológicas de caráter prático sobre o Brasil desenvolvidas pelos sociólogos rurais T. Lynn Smith e José Arthur Rios nos anos de 1940 e 1950. Suas propostas de intervenção, apontando para a reforma das estruturas sociais do campo e a multiplicação de formas de associativismo civil no país, foram gestadas em um momento em que o tema do desenvolvimento emerge com força no cenário global. Argumentamos que as sociologias de Smith e Rios se póem em continuidade com as teses de Oliveira Vianna acerca do insolidarismo e do peso do latifúndio na formação social brasileira, embora se articulem a estas de modo tenso ao visarem à efetivação da democracia política no país. Com base em textos-chaves dos sociólogos, e de fontes que lançam luzes sobre suas trajetórias, contextualizamos a produçáo intelectual de ambos, analisando igualmente o conteúdo de suas ideias e os diálogos travados com o pensamento social no Brasil.

\section{COMMUNITY AND DEMOCRACY IN THE SOCIOLOGY OF T. LYNN SMITH AND JOSÉ ARTHUR RIOS}

\section{Thiago da Costa Lopes and Marcos Chor Maio}

Keywords: The History of the social sciences; Brazilian social thought; Democracy; Community development; T. Lynn Smith; José Arthur Rios.

This article analyzes the political values embedded in the applied sociology developed by the rural sociologists T. Lynn Smith and José Arthur Rios in the 1940s and 1950s. Their proposals for social intervention, intended to modernize the Brazilian social structure and to promote civic culture among the rural poor, were conceived at a time when the theme of development emerged on the global scene. It is argued that Smith and Rios' view followed the steps of an authoritarian tradition of knowledge epitomized by the work of local intellectuals such as Oliveira Vianna, who had stressed the amorphous character of the Brazilian society. Operating within this tradition, Smith and Rios' sociology sometimes led to conclusions, which were in conflict with their goal of actualizing the Brazilian political democracy. By examining both sociologist's key texts as well as sources related to their trajectories, this article seeks to put their ideas in context and to analyze its content and relations with the Brazilian Social Thought.

\section{COMMUNAUTE ET DEMOCRATIE DANS LA SOCIOLOGIE DE T. LYNN SMITH ET DE JOSE ARTHUR RIOS}

\author{
Thiago da Costa Lopes et \\ Marcos Chor Maio
}

Mots-clés: L'histoire des sciences sociales; Pensée sociale brésilienne; Démocratie; Développement communautaire; T. Lynn Smith; José Arthur Rios.

L'article aborde, d'un point de vue transnational, la dimension politique et normative inhérente aux réflexions sociologiques de caractère pratique sur le Brésil, développées par les sociologues ruraux T. Lynn Smith et José Arthur Rios au cours des années 1940 et 1950 . Leurs propositions d'intervention, indiquant vers la réforme des structures sociales des campagnes et la multiplication des formes d'associations civiles dans le pays, ont été conçues à un moment dans lequel le thème du développement émergeait avec force sur la scène mondiale. Nous soutenons que les sociologies de Smith et de Rios se placent dans la continuité des thèses de Oliveira Vianna à propos du manque de solidarité et du poids du latifundium dans la formation sociale brésilienne, bien que s'articulant à ces dernières de façon tendue en ciblant l'achèvement de la démocratie politique au Brésil. Grâce à des textes-clés des sociologues et des sources qui portent une lumière sur leurs trajectoires, nous contextualisons leur production intellectuelle tout en analysant également le contenu de leurs idées et les dialogues qui ont eu lieu avec la pensée sociale au Brésil. 